\title{
PENERAPAN MEREK TERDAFTAR TIDAK DIGUNAKAN (NON-USE MARKS) ANALISIS KASUS ANTARA INTER IKEA SYSTEM BV DAN PT RATANIA KHATULISTIWA PUTUSAN MAHKAMAH AGUNG NO. 264 K/Pdt.Sus-HKI/2015
}

\author{
Selvy Handoyo \\ (Mahasiswa Program S1 Fakultas Hukum Universitas Tarumanagara) \\ (Email : selvy.stevy@gmail.com)
}

\section{Dr. F.X. Suyud Margono, S.H., M.Hum.}

(Corresponding Author)

(Dosen Fakultas Hukum Universitas Tarumanagara. Meraih Sarjana Hukum pada Fakultas Hukum Universitas Atmajaya, Magister Hukum pada Fakultas Hukum Universitas Tarumanagara,

Doktoral pada Fakultas Hukum Universitas Parahyangan)

(E-mail : suyudlaw@gmail.com)

\begin{abstract}
The development of business competition in the world of trade, making protection of intellectual property rights very important. Especially in the field of brands. Brand is an important thing to use to differentiate between one another by having a certain characteristic. In this paper we will discuss the case of the "IKEA" brand elimination dispute between Inter Ikea System BV and PT Ratania Khatulistiwa, where the lawsuit was filed because of the Inter Ikea System BV that have the "IKEA" brand which has not been used for 3 consecutive years. The case will be analyzed by Law Number 15 of 2001 concerning the provisions regarding the elimination of the mark and regarding the good faith of the trademark registration of application. By examining the case we can find out the proper legal application and dispute resolution in accordance with the case so that it can provide justice for the parties. In accordance with the five precepts of Pancasila, namely "Justice for all Indonesian people".
\end{abstract}

Keyword : brand, brand elimination, legal protection of the well-known brand 


\section{Pendahuluan}

\section{A. Latar Belakang}

Hak yang berasal dari intelektual manusia serta memiliki manfaat ekonomi merupakan pengertian dari Hak Kekayaan Intelektual. Dalam dunia internasional HKI dikenal dengan nama Intellectual Property Rights (yang selanjutnya disebut IPR) dimana IPR ini memiliki pengertian yaitu hak yang mempunyai kegunaan bagi kepentingan manusia, dimana hak ini timbul dari hasil pola pikir yang menghasilkan suatu produk. ${ }^{1}$

Pengertian dari Kekayaan Intelektual adalah hasil berpikir manusia yang menghasilkan suatu kreatifitas dimana hal ini bertujuan untuk mensejahterakan kehidupan manusia dengan memenuhi kebutuhannya. Aset Intelektual yang dimiliki oleh seseorang berupa kreatifitas memberikan pengaruh yang besar terhadap perkembangan manusia, yaitu berupa penemuan-penemuan (inventions) di bidang karya cipta (literary works) dan seni (art work). ${ }^{2}$

Dalam bidang Kekayaan Intelektual, sekarang ini telah mempunyai sebanyak 22 perjanjian multilateral di dalam dunia internasional. Perjanjian internasional tersebut terdiri dari konvensi-konvensi internasional, traktar yang dibuat antar negara-negara atau organisasi internasional, serta persetujuan antar negara atau organisasi internasional. Perjanjian internasional yang terbentuk diatur oleh Worls Intellectual Property Rights (selanjutnya disebut WIPO) yang berpusat di Jenewa. Perjanjian multilateral ada juga yang tidak diatur oleh WIPO contohnya Universal Copyright Convention dimana hal ini diatur oleh UNESCO.

\footnotetext{
1 Kanal Pengetahuan, "Pengertian Hak Atas Kekayaan Intelektual (Haki)", https://www.kanal.web.id/2016/10/hak-atas-kekayaan-intelektual.html, diakses tanggal 20 Desember 2018.

${ }^{2}$ Kholis Roisah, Konsep Hukum Hak Kekayaan Intelektual : Sejarah, Pengertian dan Filosofi Pengakuan HKI dari Masa ke Masa (Jatim : Setara Press, 2015) hlm. 1.
} 
Ada pula perjanjian internasional yang tidak secara khusus mengatur KI, tetapi menjadikan KI sebagai salah satu isinya. ${ }^{3}$

Persetejuan internasional di bidang KI, terbagi atas bidang hak cipta, hak milik industrial, paten, merek, desain, indikasi geografis, dan persaingan tidak sehat. Untuk bidang hak cipta tercantum dalam Konvensi Bern 1886, yang vctelah beberapa kali diubah, dan terakhir mengalami perubahan pada tahun 1967, dan merupakan konvensi induk bagi perlindungan hak cipta. Selain terdapat dalam Konvensi Bern, hak cipta juga terdapat dalam persetujuan lainnya seperti Konvensi Roma 1961, Konvensi Perlindungan bagi Prosedur Phonogram dari Tindakan Penggandaan Tanda Izin (1971), Konvensi Multilateral bagi Penghindaran Pajak Berganda atas Royalti Hak Cipta (1979), Traktat Jenewa dan Convention Relating to the Distribution of Programme Carrying Signals Transmitted by Satelite (1974).

Untuk hak milik industrial, paten, merek, desain, indikasi geografis dan persaingan tidak sehat terdapat dalam Konverensi Paris (Paris Convention) 1883 yang mengatur tentang perlindungan kekayaan industrial yang merupakan salah satu kekayaan intelektual pertama dan tetap menjadi salah satu yang terpenting karena ditandatangani oleh 151 negara. Selama ini, Konvensi Paris telah disesuaikan dan diubah secara teratur dan perjanjian TRIPs mensyaratkan semua anggota WTO untuk menerapkan prinsip-prinsipnya di dalam hukum nasionalnya masingmasing.

Selain Konverensi Paris, juga ada Konverensi Bern yang mengatur mengenai perlindungan atas karya sastra dan seni (1886) yang merupakan perjanjian utama tentang kerja sama internasional dalam bidang hak cipta serta Perjanjian TRIPs yang merupakan persetujuan internasional mengenai aspek-aspek dagang dari hak kekayaan intelektual, termasuk

\footnotetext{
${ }^{3}$ Suyud Margono, Hak Milik Industrial : Pengaturan dan Praktik di Indonesia (Bogor : Ghalia Indonesia, 2011) hlm. 26.
} 
barang-barang tiruan (trade related aspects of intellectual property right including trade in counterfeit goods). ${ }^{4}$

Di Indonesia hukum Hak atas Kekayaan Intelektual (KI) memegang peranan yang vital bagi perlindungan terhadap penerapan ide yang memiliki nilai komersial sejak diratifikasinya standar perlindungan yang ditetapkan berdasarkan Putaran Uruguay (Uruguay Round) pada tahun 1986 sampai 1994 yang menghasilkan Agreement on Trade Related Aspects of Intellectual Property rights, Inclugding Trade in Counterfernity Goods (TRIP's Agreement) seiring dengan era WTO (World Trade Organization) yang Indonesia merupakan peserta/bagian di dalamnya. ${ }^{5}$ Dengan demikian TRIP's, Paris Convention mengenai merek terkenal (well-known marks) diberlakukan terhadap barang atau jasa yang tidak sama dengan barang yang mereknya terdaftar dengan ketentuan bahwa pengguna merek dagang dalam kaitan dengan barang atau jasa menunjukan adanya hubungan antara barang atau jasa yang merek dagangnya terdaftar dan dengan ketentaun pula bahwa kepentingan pemilik merek terdaftar terganggu oleh pengguna itu. ${ }^{6}$

Dalam perkembangannya, objek perlindungan yang diatur oleh Haki secara garis besar dibagi menjadi 2 (dua) bagian, yaitu :

1. Hak Cipta (Copyright)

2. Hak Kekayaan Industrial (Industrial Property Rights), yang mencakup :

a. Paten (patent);

b. Merek (trademark);

c. Desain industri (industrial design);

d. Desain tata letaki sirkuit terpadu (layout design of integrated circuit); dan

e. Rahasia dagang (undisclosed information).

\footnotetext{
${ }^{4}$ Ibid, hlm. 26-27.

${ }^{5}$ Linsey, Hak Kekayaan Intelektual : Suatu Pengantar, (Bandung : Alumni, 2013), hlm. 23.

${ }^{6}$ Achmad Zen Umar Purba, Hak Kekayaan Intelektual Pasca TRIPs, (Bandung : Alumni, 2011), hlm. 73 .
} 
Merek adalah salah satu bagian dari HaKI yang memiliki nilai komersial dan arti penting dalam industri. Merek merupakan sebuah tanda yang dapat membedakan barang dan jasa yang diproduksi oleh suatu perusahaan terhadap perusahaan lainnya. ${ }^{7}$ Tidak hanya sebagai pembeda, merek juga digunakan oleh pengusaha untuk memberikan identitas terhadap produk barang atau jasa yang dihasilkannya.

Berdasarkan Pasal 2 Undang-Undang Nomor 20 Tahun 2016 tentang Merek dan Indikasi Geografis (yang selanjutnya disebut UU Merek dan Indikasi Geografis) menyatakan bahwa merek dibedakan menjadi merek dagang dan merek jasa. Pengertian merek dagang berdasarkan Pasal 1 Angka 2 UU Merek dan Indikasi Geografis adalahl merek yang digunakan pada barang yang diperdagangkan oleh seseorang atau beberapa orang secara bersama-sama atau badan hukum untuk membedakan dengan barang sejenis lainnya. Sedangkan pengertian merek jasa berdasarkan Pasal 1 Angka 3 UU Merek dan Indikasi Geografis adalah merek yang digunakan pada jasa yang diperdagangkan oleh seseorang atau beberapa orang secara bersama-sama atau badan hukum untuk membedakan dengan jasa sejenis lainnya.

Selain merek dagang dan merek jasa, juga dikenal merek terkenal. Merek terkenal ini tidak ada definisinya dalam UU Merek dan Indikasi Geografis, akan tetapi dalam Penjelasan Pasal 21 Ayat 1 huruf b disebutkan kriteria untuk merek terkenal.

Penggunaan merek dapat pula mencegah pihak-pihak lain yang melakukan pemasaran produk sejenis dengan menggunakan merek yang sama dapat membingungkan konsumen. Pendaftaran suatu merek merupakan hal yang sangat penting. Dalam memasarkan sebuah produk, sebuah perusahaan harus mendaftarkan merek miliknya agar merek dari produk suatu perusahaan tidak dimanfaatkan oleh perusahaan lain yang

\footnotetext{
${ }^{7}$ Henry Soelistyo, Bad Faith Dalam Hukum Merek, (Yogyakarta : PT. Maharsa Artha Mulia, 2017), hlm. 4.
} 
menggunakan merek yang sama dan memasarkan produk yang sama pula dengan perusahaan lainnya.

Selain Merek, Kekayaan Intelektual juga mewajibkan pendaftaran untuk Paten, Desain Industri, Desain Tata Letak Sirkuit Terpadu, dan Perlindungan Varietas Tanaman milik seseorang atau suatu perusahaan. Namun terdapat juga dimana pendaftarannya tidaklah diwajibkan yaitu Hak Cipta dan Rahasia Dagang karena perlindungannya tidak wajib. ${ }^{8}$ Kewajiban seseorang atau suatu pihak untuk mendaftarkan hak atas mereknya terdapat dalam Pasal 3 UU Merek dan Indikasi Geografis. Dengan didaftarkannya merek, pemilik merek mendapat hak atas merek yang dilindungi hukum. Dengan demikian, hak atas merek merupakan hak khusus yang memberikan manfaat bagi pemilik merek terdaftar dengan jangka waktu tertentu untuk menggunakan barang dan/atau jasa yang mereknya telah terdaftar.

Untuk melakukan pendaftaran merek di Indonesia ada 2 (dua) syarat yang harus dipenuhi, yang pertama adalah syarat substantif (substantive requirements) dimana persyaratan ini terdapat pada Pasal 20 dan Pasal 21 UU Merek dan Indikasi Geografis. Sedangkan untuk syarat kedua, yaitu syarat formal (formal requirements) dimana persyaratan ini terdapat pada Pasal 4 UU Merek dan Indikasi Geografis. ${ }^{9}$

Selanjutnya Pasal 23 UU Merek dan Indikasi Geografis menetapkan bahwa dalam waktu paling lama 30 (tiga puluh) hari setelah penerimaan (filling date) tidak ada keberatan, Direktorat Jenderal Kekayaan Intelektual (yang selanjutnya disebut Ditjen HKI) melakukan pemeriksaan substantif terhadap permohonan tersebut. Pemeriksaan substantif terlaksana berdasarkan ketentuan yang tertera pada Pasal 20 dan

\footnotetext{
${ }^{8}$ Tomi Suryo Utomo, Hak Kekayaan Intelektual (HKI) di Era Global : Sebuah Kajian Kontemporer, (Yogyakarta : Graha Ilmu, 2010), hlm.13.

${ }^{9}$ Rahmi Jened, Hukum Merek (Trademark Law) : Dalam Era Global dan Integrasi Ekonomi, (Jakarta : Kencana, 2017), hlm.138-139.
} 
Pasal 21 UU Merek dan Indikasi Geografis dimana akan diselesaikan dalam waktu paling lama 150 (seratus lima puluh) hari. ${ }^{10}$

Pada dasarnya bentuk pelanggaran merek yang paling pokok adalah melanggar hak eksklusif pemilik merek terdaftar yang dilindungi undang-undang. Pengertian merek terdaftar mengandung makna diakui sah dan dilindungi hukum. Dalam kaitan ini, pendaftaran merek menjadi bukti hukum yang tak terbantahkan tentang adanya hak yang sah, yaitu hak eksklusif yang melekat pada merek. Yaitu, hak untuk melarang pihak lain untuk menggunakan mereknya tanpa persetujuan. ${ }^{11}$

Apabila terjadi pelanggaran merek, pemilik merek terdaftar dapat mengajukan gugatan terhadap pihak lain yang secara tanpa hak menggunakan merek milik pihak lain. Gugatan sebagaimana disebutkan di atas diajukan kepada Pengadilan Niaga. ${ }^{12}$ Dalam Pasal 100 dan Pasal 101 UU Merek dan Indikasi Geografis juga menentukan ancaman pidana kepada setiap orang yang menggunakan merek yang sama pada keseluruhannya ataupun yang sama pada pokoknya. ${ }^{13}$

Meski pada praktiknya telah ada aturan tentang merek yang mengatur namun tetap saja sering terjadi persengketaan merek antara pelaku usaha. Dimana dari tahun 2015 (dua ribu lima belas) hingga April 2018 (dua ribu delapan belas) terdapat 211 (dua ratus sebelas) kasus sengketa merek.

Dari beberapa kasus tersebut, terdapat salah satu kasus sengketa merek yang akan penulis angkat, yaitu sengketa merek "IKEA" antara Inter Ikea System B.V. asal Swedia dengan PT. Ratania Khatulistiwa asal Surabaya yang telah diputus berdasarkan Putusan Mahkamah Agung Nomor 264 K Pdt.Sus-HKI/2015 jo Putusan Pengadilan Niaga Jakarta Pusat Nomor 99/PDT.SUS-MEREK/2013/PN.Niaga.Jkt.Pst.

\footnotetext{
${ }^{10}$ Ibid, hlm.149.

${ }^{11}$ Henry Soelistyo, Op.Cit., hlm.140.

12 Adrian Sutedi, Hak Atas Kekayaan Intelektual, (Jakarta : Sinar Grafika, 2013), hlm. 95-96.

${ }^{13}$ Ibid, hlm. 97.
} 
Sengketa merek terkenal IKEA ini bermula pada tahun 2013, dimana PT. Ratania Khatulistiwa mengajukan gugatan penghapusan permohonan pendaftaran merek dagang "IKEA" milik Inter Ikea System B.V. untuk kelas barang jenis $20^{14}$ dan $21^{15}$. Dalam gugatannya, PT. Rataniai Khatulistiwa lberdalih bahwa lmerek dagang imilik Ikea iSwedia telah tidak digunakan selama 3 tahun berturut-turut sejak tanggal pendaftarannya di Indonesia untuk kelas barang jenis 20 dan 21.

Alasan gugatan tersebut diperkuat dengan adanya hasil market survey Berlian Group Indonesia (BGI), yang merupakan lembaga yang netral dan independen dalam melakukan market survey di Indonesia menyimpulkan bahwa produk-produk dengan merek "IKEA" atas nama Inter Ikea System B.V. untuk kelas 20 dan kelas 21 tidak pernah dijual maupun diedarkan di seluruh wilayah Indonesia.

Berdasarkan hasil market survey tersebut, PT. Ratania Khatulistiwa mengajukan gugatan penghapusan merek dagang "IKEA" milik Inter Ikea System B.V. dari daftar umum merek ke Pengadilan Niaga Jakarta Pusat, dimana Pengadilan Niaga Jakarta Pusat memutus mengabulkan gugatan tersebut. Berdasarkan putusan tersebut, Inter Ikea System B.V mengajukan kasasi ke Mahkamah Agung, yang kemudian menolak kasasi yang diajukan oleh Inter Ikea System B.V. ${ }^{16}$

Hal yang tidak diungkapkan dalam pengadilan yaitu adanya registrasi ulang ke Ditjen HKI yang dilakukan oleh Inter Ikea System B.V. pada bulan maret tahun 2012 dan disetuju atau terdaftar pada

\footnotetext{
${ }^{14}$ Kelas barang jenis 20 : perabot-perabot rumah, cermin, bingkai gambar, benda-benda (yang tidak termasuk dalam kelas-kelas lain) dari kayu, gabus, rumput, buluh, rotan, tanduk, tulang, gading, balein, kulit kerang, amber, kulit mutiara, tanah liat magnesium, dan bahan-bahan penggantinya, atau dari plastik.

${ }^{15}$ Kelas barang jenis 21 : perkakas dan wadah-wadah untuk rumah tangga atau dapur (bukan dari logam mulia atau yang dilapisi logam mulia); sisir-sisir dan bunga-bunga karang, sikat-sikat (kecuali kuwas-kuwas); bahan pembuat sikat; benda-benda untuk membersihkan; wol; baja; kaca yang belum atau setengah dikerjakan (kecuali kaca yang dipakai dalam bangunan); gelas-gelas, porselin dan pecah belah dari tembikar yang tidak termasuk dalam kelas-kelas lain.

${ }^{16}$ Lembar Putusan Mahkamah Agung Nomor 264 K Pdt.Sus-HKI/2015.
} 
tanggal 4 Juni tahun 2014 untuk semua kelas jenis barang dan/atau jasa merek dagang "IKEA" termasuk kelas barang jenis 20 dan $21 .^{17}$

Berdasarkan uraian-uraian di atas, maka penulis tertarik untuk melakukan penelitian lebih lanjut dengan judul "Penerapan Merek Terdaftar Yang Tidak Digunakan (Non-Use Marks) Analisis Kasus Inter Ikea System BV dan PT. Ratania Khatulistiwa Putusan Mahkamah Agung Nomor 264 K/Pdt.Sus-HKI/2015”.

\section{B. Perumusan Masalah}

Berdasarkan apa yang telah diuraikan pada latar belakang di atas, permasalahan dalam penelitian ini adalah bagaimana penerapan hukum bagi pemilik merek terdaftar yang tidak digunakan berdasarkan UU Merek di Indonesia?

\section{Metode Penelitian}

Penelitian hukum merupakan suatu bentuk kegiatan menganalisis, dimana analisis ini berdasarkan pada metode penelitian dan suatu proses berpikir secara sistematis yang bertujuan untuk memperoleh suatu pembelajaran atau beberapa gejala hukum. Disamping kegiatan tersebut, diadakan juga pemeriksaan terhadap suatu faktor hukum secara lebih mendalam, yang kemudian diusahakan untuk mendapatkan penyelesaian atas permasalahan-permasalahan hukum yang muncul dalam gejala hukum yang bersangkutan. ${ }^{18}$

\section{Jenis Penelitian}

Dalam penelitian ini, jenis penelitian hukum normative merupakan jenis penelitian yang digunakan oleh penulis. Pengertian penelitian

17 BBC Indonesia. MA Hapuskan Merek, Toko IKEA di Indonesia Tetap Buka, http://www.bbc.com/indonesia/majalah/2016/02/160213_majalah_bisnis_indonesia_ikea, diunduh pada hari Sabtu, tanggal 7 April 2018, pukul 10.00 WIB.

${ }^{18}$ Soerjono Soekanto, Pengantar Penelitian Hukum, (Jakarta : UI Press, 2010) hlm.43. 
hukum normative sendiri adalah suatu penelitian yang mengacu kepada peraturan perundang-undangn dimana didalamnya terdapat norma-norma hukum yang digunakan sebagai bahan acuan dalam penelitian. $^{19}$

\section{Jenis Data}

Jenis data yang digunakan peneliti dalan penelitian ini adalah jenis data sekunder, ${ }^{20}$ dimana sumber data yang digunakan oleh peneliti dalam penelitian ini yaitu sumber data kepustakaan berupa peraturan perundang-undangan, buku-buku, artikel serta sumber data kepustakaan lainnya.

Dalam penelitian ini, terdapat 3 (tiga) jenis bahan hukum yaitu bahan hukum primer, bahan hukum sekunder dan bahan hukum tersier. Dibawah ini dijelaskan pengertian dari jenis bahan-bahan hukum tersebut $^{21}$

a. Bahan hukum primer merupakan bahan hukum dimana mmpunyai isi yang berkekuatan mengikat kepada masyarakat. Terkait dengan permasalahan yang dibahas bahan hukum primer yang penulis gunakan yaitu Undang-Undang Merek, TRIPs serta putusan Mahkamah Agung No.264 K Pdt.Sus-HKI/2015.

b. Bahan hukum sekunder adalah bahan hukum yang isinya memberikan informasi berkaitan dengan bahan hukum primer. Dalam hal ini bahan hukum sekunder yang dimaksud adalah jurnal, makalah maupun buku mengenai merek dagang terkenal dan juga memuat ketentuan-ketentuan maupun teori-teori dan pandanganpandangan terkait dengan tanggung jawab Direktorat Jenderal HKI terhadap dugaan merek dagang terkenal yang tidak digunakan.

\footnotetext{
${ }^{19}$ Ibid, hlm. 10.

${ }^{20}$ Soerjono Soekanto dan Sri Mamudji (2), Penulisan Hukum Normatif, cetakan ke-7, (Jakarta : Raja Grafindo, 2004), hlm.24.

${ }^{21}$ Ibid, hlm. 33.
} 
c. Bahan hukum tersier adalah bahan hukum yang merupakan lanjutan dari bahan hukum primer dan bahan hukum sekunder, yaitu berupa petunjuk maupun penjelasan terhadap bahan hukum tersebut. Dalam hal ini bahan hukum tersier yang penulis gunakan adalah kamus-kamus hukum.

\section{Teknik Pengumpulan Data}

Teknik pengumpulan data yang digunakan penulis dalam penelitian ini yaitu mengutamakan studi dokumen atau bahan-bahan pustaka karena sumber data sekunder merupakan sumber data yang digunakan oleh penulis, sehingga teknik pengumpulan data yang tepat untuk digunakan dalam penelitian ini adalah dokumentasi dengan melakukan studi dokumen ke perpustakaan atau ke pusat dokumen hukum lainnya dan wawancara kepada narasumber.

\section{Pendekatan Penelitian}

Dalam penelitian hukum normatif dikenal beberapa pendekatan - pendekatan guna memperoleh suatu informasi dari berbagai aspek untuk mencari jawaban terhadap isu permasalahan yang sedang diteliti. Dalam penelitian ini, pendekatan yang digunakan penulis antara lain:

a. Pendekatan Undang - Undang (Statute Approach)

Pendekatan undang-undang (statute approach) adalah pendekatan yang dilakukan dengan menelaah semua peraturan perundangundangan dan regulasi yangi berkaitan dengani isu hukum yang sedang dibahas. ${ }^{22}$

b. Pendekatan Kasusl (Case Approach)

${ }^{22}$ Peter Mahmud Marzuki, Penelitian Hukum, Edisi Revisi (Jakarta : Prenadamedia Group, 2015), hlm. 133. 
Pendekatan kasus (case approach) yaitu pendekatan yang dilakukan dengan cara melakukan telaah terhadap kasus-kasus yang berkaitan dengan isu hukum yang tengah dihadapi dimana kasus tersebut telah menjadi putusan pengadilan yang telah mempunyai kekuatan hukum yang tetap. ${ }^{23}$

c. Pendekatan Konseptual (Conceptual Approach)

Pendekatanl konseptual (conceptual approach) yaitu pendekatan yang menganalisis dari pandangan - pandangan dan doktrin doktrin yang berkembang di dalam ilmu hukum. ${ }^{24}$

\section{Pembahasan}

Perlindungan terhadap suatu merek dapat terjadi apabila merek tersebut telah didaftarkan dan telah terdaftar di Daftar Umum Merek di Ditjen HKI. Pendaftaran merek merupakan suatu proses yang membutuhkan waktu yang lama, bukan ketika permohonan suatu merek diajukan kemudian merek akan langsung terdaftar. Ketika permohonan pengajuan merek dilakukan oleh seseorang atau sebuah pihak dengan ketentuan yang telah ditetapkan, kemudian Ditjen HKI akan memberikan nomor permohonan dan tanggal penerimaan permohonan merek.

Dalam pendaftaran merek terdapat 2 (dua) tahapan yangi harus dilalui agar sebuah merek dapat didaftarkan yaitu pemeriksaan administratif dan pemeriksaan substantif. Pemeriksaan administratif adalah pemeriksaan terhadap kelengkapan dalam hal pemenuhan persyaratan. Apabila ada kekurangan Ditjen HKI akan memintai kelengkapan persyaratan tersebut untuk dipenuhi dalam waktu paling lama 2 (dua) bulan. Apabila seluruh persyaratan administratif telah dipenuhi oleh pemohon iterhadap permohonan tersebut akan diberi tanggap penerimaan (filling date) yang dicatat di Ditjen HKI. Dalam jangka waktu 30 (tiga puluh) hari terhitung sejak

\footnotetext{
${ }^{23}$ Ibid, hlm. 134.

${ }^{24}$ Ibid, hlm. 135.
} 
tanggal penerimaan, maka Ditjen HKI akan melakukan pemeriksaan substantif paling lama 9 (Sembilan) bulan. Pemeriksaan substantif akan dilakukan dengan pemeriksaan yang berkaitan dengan Pasal 4, Pasal 5 dan Pasal 6 UU Merek. Setelah dilakukan pemeriksaan substantif, maka Ditjen HKI akan melakukan pengumuman selama 3 (tiga) bulan untuk menunggu sanggahan dari masyarakat. Jika merek yang dimohonkan tidak mendapat sanggahan, maka merek akan secara resmi telah terdaftar di Daftar Umum Merek, dan selanjutnya Ditjen HKI akan menerbitkan sertifikat pendaftaran merek.

Pendaftaran merek harus didasarkan pada prinsip iktikad baik (good faith) dari pendaftar yang berdasarkan pada UU Merek. Berdasarkan prinsip ini, hanya pendaftar dengan iktikad baiklah yang akan mendapatkan perlindungan hukum. Hal ini membuat Ditjen HKI berkewajiban secara aktif untuk menolak pendaftaran merek bilamana secara nyata ditemukan adanya kemiripan atau peniruan dengan suatu merek yang didaftarkan dengan dasar iktikad tidak baik (bad faith). Hal ini bertujuan dalam hal untuk melindungi merek yang telah terdaftar. Ketentuan ini dapat ditemukan dalam Pasal 4, Pasal 5 dan Pasal 6 UU Merek sedangkan dalam UU Merek dan Indikasi Geografis dapat ditemukan dalam Pasal 20 dan Pasal 21. Dalam Kitab Undang-Undang Hukum Perdata (yang selanjutnya disebut dengan KUHPerdata) menggunakan istilah iktikad baik dalam 2 (dua) pengertian, yaitu iktikad baik dalam pengertian subjektif dan dalam arti objektif. Iktikad baik dalam arti subjektif disamakan maknanya dengan kata kejujuran. Hal ini tersirat dalam ketentuan Pasal 530 KUHPerdata yang mengatur mengenai kedudukan berkuasa (bezit). Iktikad baik dalam arti subjektif juga dapat dimaknai sebagai sikap batin untuk bertindak kejujuran.

Selanjutnya iktikad baik dalam arti objektif dimaknai dengan kepatutan. Prinsip ini ditegaskan dalam Pasal 1338 Ayat (3) KUHPerdata yang berbunyi "Suatu perjanjian harus dilaksanakan dengan iktikad baik". Iktikad baik dalam Pasal 1338 Ayat (3) KUHPerdata sebenarnya bukan merupakan syarat bagi sahnya suatu perjanjian sebagaimana syarat yang diamanatkan dalam ketentuan Pasal 1320 KUHPerdata. Dalam kaitannya 
dengan hal ini, unsur iktikad baik hanya disyaratkan dalam hal "pelaksanaan" dari suatu kontrak, bukan pada "pembuatan" suatu kontrak. Karena unsur "iktikad baik" dalam hal pembuatan kontrak sudah dapat dicakup dalam unsur "kausa yang legal" atau kausa yang halal sebagaimana ditegaskan dalam Pasal 1320 KUHPerdata tersebut. Sehingga arti dari iktikad baik yang bersifat subjektif adalah sebagai sebuah kejujuran seseorang dalam melakukan suatu perbuatan hukum, yaitu apa yang ada dalam sikap batin seseorang pada saar melakukan perbuatan hukum. Sedangkan iktikad baik dalam pengertian objektif, merujuk pada keharusan pelaksanaan suatu perjanjian untuk senantiasa didasarkan pada norma kepatutan atau kelayakan sesuai dengan pandangan masyarakat.

Dalam hal kasus sengketa merek "IKEA" antara Penggugat Kasasi dan Tergugat Kasasi, dapat dilihat bahwa Tergugat Kasasi tidak memiliki iktikad baik, dimana ini terlihat dari tuntutan yang diajukan oleh Tergugat Kasasi dalam Putusan Pengadilan Niaga Jakarta Pusat. Tuntutan yang diajukan Tergugat Kasasi adalah untuk menghapuskan merek "IKEA" milik Penggugat Kasasi dalam kelas barang 20 dan 21 dan menyatakan permohonan pendaftaran merek Tergugat Kasasi di kelas barang yang sama adalah sah. Dapat dilihat Majelis Hakim tidak mempertimbangkan adanya persamaanpersamaan antara merek IKEA Penggugat Kasasi dan merek IKEA Tergugat Kasasi yang dapat dilihat sebagai berikut :

1. Persamaan unsur yang membentuk kata IKEA. Di dalam Merek IKEA milik Penggugat Kasasi, dengan unsur yang membentuk kata IKEA dalam merek IKEA milik Tergugat Kasasi yaitu kombinasi huruf I-K-E-A. Dimana uraian dari merek IKEA milik Penggugat Kasasi adalah:

I : Ingvar

K : Kamprad

E : Elmtaryd

A : Agunnaryd

Sedangkan uraian untuk merek IKEA Tergugat Kasasi adalah :

I : Intan, akronim dari industr rotan; 
$\mathrm{K}$ : Khatulistiwa, merupakan bagian dari nama badan hukum Tergugat Kasasi (PT. Ratania Khatulistiwa);

E : Esa, yang berarti satu atau tunggal;

Ai : Abadi, yang berarti kekal atau selamanya.

Walaupun merek IKEA dari Penggugat Kasasi dan merek IKEA Tergugat Kasasi memiliki uraian makna yang berbeda tetapi kombinasi huruf yang digunakan oleh Tergugat Kasasi dalam pendaftaran mereknya adalah sama.

2. Persamaan bunyi ucapan antara kata IKEA milik Penggugat Kasasi dan merek IKEA milik Tergugat Kasasi.

3. Persamaan jenis barang antara produk yang dilindungi di dalam merek IKEA milik Penggugat Kasasi dengan produk milik Tergugat Kasasi, dimana menggunakan merek IKEA dalam kelas barang 20 dan 21.

Persamaan - persamaan yang terdapat dalam merek IKEA Tergugat Kasasi seharusnya dapat dipertimbangkan dalam putusan Pengadilan Niaga serta dalam putusan Mahkamah Agung. Selain tidak mempertimbangkan persamaan - persamaan pada merek IKEA Penggugat Kasasi dan Tergugat Kasasi Majelis Hakim juga tidak mempertimbangkan keterkenalan merek IKEA milik Penggugat Kasasi. Ketentuan mengenai merek terkenal dapat dilihat dalam Pasal 6 Ayat (1) huruf (b) UU Merek sedangkan dalam UU Merek dan Indikasi Geografis terdapat dalam Pasal 21 Ayat (2) huruf (b) yang menyatakan bahwa permohonan suatu merek harus ditolak oleh Direktorat Jenderal apabila merek tersebut mempunyai persamaan pada pokoknya atau keseluruhannya dengan merek yang sudan terkenal milik pihak lain untuk barang dan/atau jasa sejenis.

Berdasarkan Pasal 28 UU Merek dan Pasal 35 Ayat (1) UU Merek dan Indikasi Geografis menyatakan bahwa perlindungan terhadap merek terdaftar dilindungi dalam waktu 10 (sepuluh) tahun sejak tanggal penerimaan pendaftaran merek dan jangka waktu perlindungan tersebut dapat diperpanjang. Jangka waktu perlindungan sebuah merek terdaftar diberikan dengan menyesuaikan pada prinsip keadilan yaitu jangka waktu penggunaan yang layak sebuah merek adalah 7 (tujuh) tahun (vide Article 18 TRIPs). 
Apabila disesuaikan dengan UU Merek di Indonesia yang memberikan jangka waktu perlindungan selama 10 tahun, dapat dilihat jangka waktu perlindungan dalam ketentutan UU Merek Indonesia lebih lama dibandingkan dengan apa yang telah ditentukan dalam TRIPs. ${ }^{25}$

Namun, berbeda perlindungannya ketika merek yang telah didaftarkan kemudian tidak digunakan. Dalam hal ini, merek yang telah didaftarkan tersebut dapat dihapuskan jika merek terdaftar tersebut tidak dipergunakan dalam waktu 3 (tiga) tahun secara berturut-turut sejak tanggal pendaftaran. Selain karena tidak dipergunakan, suatu merek juga dapat dihapuskan apabila merek yang digunakan tidak sesuai dengan yang didaftarkan, dimana ketentuan ini terdapat dalam Pasal 61 UU Merek.

“(1) Penghapusan pendaftaran Merek dari Daftar Umum Merek dapat dilakukan atas prakarsa Direktorat Jenderal atau berdasarkan permohonan pemilik Merek yang bersangkutan.

(2) Penghapusan pendaftaran Merek atas prakarsa Direktorat Jenderal dapat dilakukani jika :

a. Merek tidak digunakan selama 3 (tiga) tahun berturutturut dalam perdagangan barang dan/atau jasa sejak tanggal pendaftaran atau pemakaian terakhir, kecuali apabila ada alasan yang dapat diterima oleh Direktorat Jenderal;

b. Merek digunakan untuk jenis barang dan/atau jasa yang tidak sesuai dengan jenis barang atau jasa yang dimohonkan pendaftaran, termasuk pemakaian Merek yang tidak sesuai dengan Merek yang didaftar.

Dalam penjelasan Pasal 61 Ayat (2) huruf (a) juga dijelaskan maksud dari pemakaian terakhir, yaitu :

"Yang dimaksud dengan pemakaian terakhir adalah penggunaan merek tersebut pada produksi barang atau jasa yang diperdagangkan. Saat pemakaian terakhir tersebut dihitung dari tanggal terakhir pemakaian sekalipun setelah itu barang yangi bersangkutan masih beredar d masyarakat."

\footnotetext{
${ }^{25}$ Rahmi Jened, hlm.188.
} 
Berdasarkan penjelasan di atas dapat dilihat bahwa bukti-bukti yang diajukan oleh Pemohon Kasasi tersebut merupakan bukti sempurna yang memenuhi unsur perdagangan.

Pengertian yang dimaksud dengan pemakaian terakhir dari suatu penggunaan merek di dalam perdagangan barang dan/atau jasa tidak dijelaskan di dalam UU Merek maupun di dalam UU Merek dan Indikasi Geografis. Hal ini sangatlah penting karena di dalam persidangan, Termohon Kasasi harus dapat membuktikan kapan pemakaian terakhir merek milik Pemohon Kasasi digunakan dalam perdagangan atau dengan kata lain kapan merek milik Pemohon Kasasi tidak giunakan dalam perdagangan barang ataupun jasa. Hal ini sangatlah penting dalam hal pembuktian yang harus disampaikan Termohon Kasasi dalam mengajukan tuntutannya.

Peraturan merek di Indonesia, pada dasarnya mengacu kepada Trade Related Aspects Of Intellectual Property Rights (yang selanjutnya disebut TRIPs), penghapusan pendaftaran suatu merek tidak diatur di dalam TRIPs. Ynag diatur di dalam TRIPs hanyalah mengenai pembatalan suatu merek dimana hal ini dapat terjadi apabila suatu merek tidak digunakan dalam waktu setidaknya 3 (tiga) tahun berturut-turut. Hal ini terdapat di dalam Pasal 19 TRIPs yang isinya sebagai berikut :

" 1 . If use required to maintain a registration, the registration may be cancelled only after an uninterrupted period of at least three years of non-use, unless valid reasons based on the existence of obstacles to such use are shown by the trademark owner. Circumstances arising independently of the will of the owner of the trademark which constitute an obstacle to the use of the trademark, such as import restrictions on or other government requirementfor goods or services protected bt the trademark, shall be recognized as valid reasons for non-use."

Ketentuan yang disebutkan di atas, dalam UU Merek di Indonesia merupakan sebagai syarat penghapusan suatu merek terdaftar, bukan merupakan syarat pembatalan suatu merek. Yaitu dimana pemilik merek tidak menggunakan mereknya dalam perdagangan barang dan/atau jasa setelah merek tersebut terdaftar di dalam Daftar Umum Merek di Ditjen HKI. Selain 
itu merek tersebut juga tidak pernah dipakai kembali selama 3 (tiga) tahun berturut-turut. $^{26}$

Yang dimaksud dengan pemakaian terakhir adalah penggunaan terkahir suatu merek di dalam perdagangan barang dan/atau jasa, atau sejak tanggal produksi terakhir suatu merek digunakan, tanpa melihat atau mempertimbangkan barang dan/atau jasa tersebut masih beredar atau tidak di masyarakat.$^{27}$

Menurut Rahmi Jened, ketentuan mengenai penggunaan terakhir suatu merek dalam perdagangan barang dan/atau jasa di dalam ketentuan "non-use marks" seharusnya dihitung dalam jangka waktu 3 (tiga) tahun.$^{28}$

Dalam kasus sengketa merek "IKEA" yang digugat penghapusan oleh pihak ketiga, harus dicermati secara lebih mendalam. Hal ini dikarenakan ketentuan yang terdapat di dalam Black's Law Dictionary yang menyatakan bahwa :.29 "One not a party to an agreement, a transaction, or an action, but who have rights there in". 30

Berdasarkan ketentuan di atas, berdasarkan Pasal 63 UU Merek dapat kita ketahui bahwa pihak ketiga yang mempunyai hak untuk mengajukan gugatan penghapusan terhadap suatu merek terdaftar adalah pihak yang memiliki hak untuk melakukan tuntutan atau gugatan tersebut. Pihak yang berada di luar suatu perjanjian atau pun apabila terdapat pihak di dalam proses transaksi, pihak yang dimaksud adalah pihak yang tidak dapat melakukan suatu tindakan hukum, pihak - pihak tersebut tidak dapat mengajukan gugatan penghapusan merek. $^{31}$

Berdasarkan dengan suatu merek, suatu merek yang dimiliki oleh seseorang atau sebuah badan hukum tidak boleh sama atau dengan kata lain

\footnotetext{
${ }^{26}$ Dwi Rezki Sri Astarini, Penghapusan Merek Terdaftar Berdasarkan UU No.15 Tahun 2001 Tentang Merek Dihubungkan Dengan TRIPs-WTO, PT. Alumni, Bandung, 2009, hlm. 79.

${ }^{27}$ Ibid., hlm. 82.

${ }^{28}$ Rahmi Jened, Op.Cit., hlm. 305.

${ }^{29}$ Ibid., hlm. 307.Dikutip dari Henry Campbell Black, Black's Law Dictionary, West Publishing, St. Paul Minn, 1996, hlm.1479.

30 "Seseorang yang bukan pihak dalam suatu perjanjian, bukan pihak lain dalam suatu transaksi atau suatu tindakan hukum, tetapi orang yang memiliki hak untuk itu."

${ }^{31}$ Rahmi Jened, Op.Cit., hlm. 304.
} 
harus memiliki daya pembeda dengan merek milik pihak lain. Suatu merek harus memilik daya pembeda atau tidak boleh sama dengan pihak lain dalam hal secara keseluruhannya, atau yang pada prinsipnya suatu merek itu dapat dianggap sama, apabila suatu merek terdapat persamaan maka dapat dikatakan bahwa merek tersebut telah meniru merek pihal lain. Sehingga dapat disimpulkan pengertian dari persamaan pada pokoknya atau keseluruhannya yaitu dalam suatu merek terdapat unsur - unsur yang memiliki persamaan atau kemiripan dengan merek milik pihak lain, dimana hal ini dapat menimbulkan anggapan bahwa merek tersebut memiliki persamaan dalam hal bentuk, penulisannya, gambarnya, symbol atau logonya, kombinasi - kombinasinya, ataupun persamaan bunyi pada pengucapannya, semua unsur - unsur yang ada dalam sebuah merek.

Berdasarkan kasus sengketa merek IKEA, yang disesuaikan dengan hal "persamaan pada pokoknya atau keseluruhannya" dapat disimpulkan merek IKEA milik Termohon Kasasi yang dimohonkan pendaftaran mereknya tersebut memiliki persamaan pada pokoknya atau keseluruhannya dengan merek IKEA milik Pemohon Kasasi.

Penamaan merek IKEA yang berasal dari nama dari pendiptanya sekaligus pemilik dari merek IKEA sendiri yang bersala dari Swedia, dimana merek IKEA merupakan singkatan dari Ingvar Kamprad Elmtaryd Agunnaryd. Nama - nama tersebut masing-masing memiliki arti. Ingvar merupakan nama depan pendiri perusahaan Pemohon Kasasi, Kamprad merupakan nama keluarga dari pendiri perusahaan Pemohon Kasasi, Elmtaryd merupakan nama tempat pertanian dimana Ingvar Kamprad tersebut beranjak dewasa, Agunnaryd merupakan nama dari persekutuan gereja dimana Ingvar Kamprad menjadi salah satu anggota jemaat. Dapat dilihat bahwa merek IKEA milik Pemohon Kasasi bukan merupakan bahasa umum serta mempunyai ciri khas sendiri, sehingga dapat dikatakan merek IKEA Pemohon Kasasi merupakan 
merek yang diciptakan atau ditemukan, yang dalam Bahasa Inggris dinamakan dengan istilah "coined mark" atau "invented mark". ${ }^{32}$

Apabila kita lihat dari segi logo, baik logo milik Pemohon Kasasi maupun logo milik Termohon Kasasi, bila dilihat sekilas memiliki kemiripan antara satu dengan lainnya. Di bawah ini merupakan gambar dari masing masing logo yang dimiliki Pemohon Kasasi dan Termohon Kasasi.

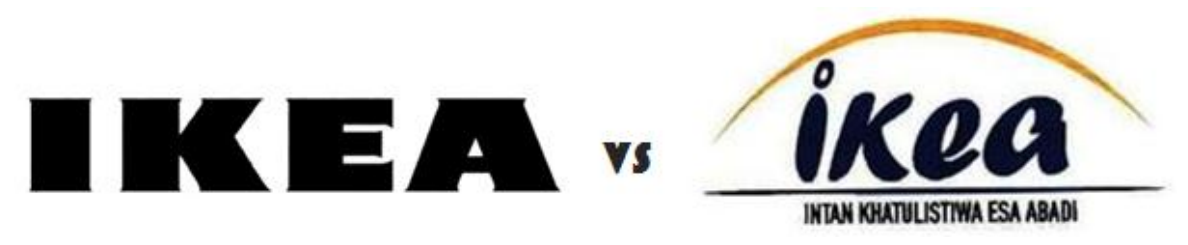

Bagian kiri pada gambar merupakan logo IKEA milik Pemohon Kasasi pada tahun 1967 dan pada bagian kanan gambar merupakan logo IKEA milik Termohon Kasasi. Di bawab ini merupakan logo baru merek IKEA milik Pemohon Kasasi.

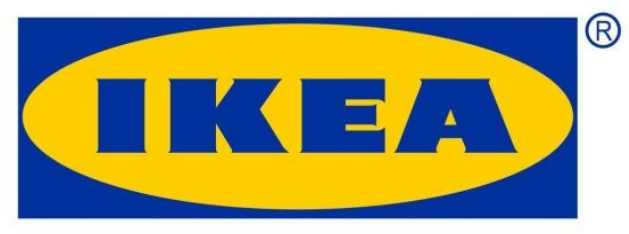

Berdasarkan gambar di atas, terlihat jelas bahwa logo milik Pemohon Kasasi dan Termohon Kasasi memiliki persamaan. Persamaan - persamaan tersebut terlihat dari penyusunan huruf-hurufnya, persamaan bunyi dalam pengucapannya serta dalam hal gambar visualnya yang dapat dikatakan bahwa hal ini telah melanggar fungsi dari sebuah merek.

Ketentuan mengenai "persamaan pada pokoknya" diatur di dalam Pasal 6 Ayat (1) huruf (a) dan IPasal 90 UU Merek. Dalam Pasal 6 Ayat (1) huruf (a) UU Merek mengatur mengenai :

"Permohonan harus ditolak oleh Direktorat Jenderal apabila merek tersebut :

(a) Mempunyai persamaan pada pokoknya atau secara keseluruhannya dengan merek pihak lain yang sudah terdaftar lebih dahulu untuk barang dan/atau jasa yang sejenis. “

\begin{tabular}{ccccc}
\hline 32 & Putusan Pengadilan & Niaga Jakarta & Pusat & Nomor 99/PDT.SUS- \\
MEREK/2013/PN.NIAGA.Jkt.Pst.
\end{tabular}


Dalam Pasal 90 UU Merek diatur mengenai :

"Barangsiapa dengan sengaja dan tanpa hak menggunakan merek yang sama pada keseluruhannya dengan lmerek terdaftar milik pihak lain untuk barang dan/atau jasa yang sejenis yang diproduksi dan/atau diperdagangkan, dipidana dengan pidana penjara paling lama 5 (lima) tahun dan/atau paling banyak denda 1 miliyar rupiah"

Kasus sengketa merek IKEA antara Inter Ikea System BV sebagai Pemohon Kasasi dan PT. Ratania Khatulistiwa sebagai Termohon Kasasi menitikberatkan pada penghapusan merek IKEA yang tidak dipergunakan selama 3 (tiga) tahun berturut-turut sejak tanggal pendaftaran merek. Tetapi apabila kita cermati lebih dalam, Termohon Kasasi melakukan gugatan terhadap Pemohon Kasasi dengan maksud agar Termohon Kasasi dapat menggunakan merek IKEA dalam perdagangan. Penulis berpendapat, bahwa Termohon Kasasi telah beriktikad tidak baik karena Termohon Kasasi ingin menggunakan merek IKEA dalam perdagangan sehingga menggugat Pemohon Kasasi, selain itu juga Termohon Kasasi ingin membonceng keterkenalan merek IKEA milik Pemohon Kasasi. Perbuatan yang diperbuat oleh Termohon Kasasi dapat menimbulkan kebingungan dan kekeliruan serta dapat menyesatkan konsumen yaitu masyarakat luas.

Dalam Pasal 4 UU Merek yang mengatur mengenai iktikas baik dari pemohon pendaftar merek dapat kita lihat juga di dalam penjelasan Pasas 4 UU Merek yaitu sebagai berikut :

"Pemohon yang beriktikad baik adalah pemohon yang mendaftarkan mereknya secara layak dan jujur tanpa ada niat apa pun untuk membonceng, meniru, atau menjiplak ketenaran merek pihak lain demi kepentingan usahanya yang berakibat kerugian pada pihak lain itu atau menimbulkan kondisi persaingan curang, mengecoh, atau menyesatkan konsumen."

Dari penjelasan di atas dapat kita ketahui bahwa niat untuk membonceng, meniru atau menjiplak ketenaran merek milik pihak lain dapat mengakibatkan kerugian bagi pihak lain yang mereknya telah ditiru. Selain itu 
juga dapat mengecoh serta menyesatkan konsumen. "Persamaan pada pokoknya atau keseluruhannya" dan "merek terkenal" dapat juga dikaitkan dengan penjelasan Pasal 4 UU Merek.

Dari uraian di atas dapat disimpulkan bahwa seseorang tidak dapat mendaftarkan mereknya dengan niat untuk meniru ketenaran yang mengakibatkan kerugiani pada pihak lain, sehingga dapat menimbulkan persaingan yang curang, dapat mengecoh, serta menyesatkan konsumen.

Adapun kasus lain mengenai penghapusan merek lain atas dasar "non-use" ialah kasus penghapusan merek Intel antara Intel Corp melawan PT. Tanggung. Intel Corporation adalah perusahaan Amerika terkemuka di bidang iinovasi silicon dani pengembangani teknologi, imengajukan gugatan penghapusan merek Intel miliki PT. Tanggung. Gugatan penghapusan diajukan karena adanya bukti dari hasi survei pasar di enam kota besar di Indonesia : Jakarta, Surabaya, Medan, Bandung, Makasar, dan Pontianak yang menyatakan bahwa tidak ada penjualan ataupun produksi barang-barang elektronik bermerek Intel oleh PT. Tanggung. ${ }^{33}$ Bukti tersebut sama dengan bukti pada kasus penghapusan merek "IKEA", tetapi walaupun memiliki bukti yang sama, pengadilan memutuskan hal yang berbeda. Dalam kasus merek Intel, walaupun hakim mengakui bahwai merek iIntel imilik iPT. Tanggungi tidak llagi ditemukanl dalam perdagangan, namun majelis hakim memutuskan untuk menolak gugatan penghapusan dengan pertimbangan bahwa penggugat tidak dapat menentukan secara jelas kapan terakhir kalinya merek Inter dipakai oleh PT. Tanggung sehingga menyatakanl bahwa gugatan ltidak ldapat lmenentukan lsecara jelas kapanl terakhir kalinya merek Intel dipakai oleh PT. Tanggung sehingga menyatakan gugatan penghapusan dianggap tidak jelas (obscure libel) dan tidak dapat diterima (niet onvantkelijkeheid).

Berdasarkan uraian diatas, menurutl penulis jika hal mengenai tanggal penggunaan merek terakhir kali harus jelas, maka seharusnya hal tersebut juga diterapkan pada gugatan penghapusan mereki IKEA. Yang

\footnotetext{
${ }^{33}$ Ibid., hlm. 306
} 
perlu diketahui bahwa merek yang digugat penghapusan memang benar-benar tidak digunakan dan tentang tanggal penggunaan terakhir suatu merek harus jelas, sehingga tidak terjadi kesalahan dalam mengambil putusan. Secara jelas bahwa Pemohon Kasasi yaitu Inter Ikea System BV dapat imembuktikan bahwai barang dengani merek IKEA masih dipergunakan dan diproduksi di Indonesia. Sebaiknya Majelis Hakim dapat mempertimbangkan bukti-bukti yang diberikan oleh Pemohon Kasasi. Adanya perbedaan dalam memutuskan perkara yang sama akan membuat masyarakat bingung dengani sistem ihukum yang iberlaku. Dalami hall ini, lpenulis lmemberikan pandangan bahwal seharusnya majelis hakim dapat lmenerapkan lperaturan yang samal untuk kasus dengan gugatan danl bukti yang sama, agar tidak membingungkan masyarakat dan memberikan keadilan bagi masing-masing pihak.

Berdasarkan penjelasan di atas, dapat dilihat dalam kasus Inter Ikea System BV melawan PT. Ratania Khatulistiwa, hakim tidak mempertimbangkan iktikad baik dalam memutuskan perkara, walaupun dalam dalil yang diajukan oleh Inter Ikea System BV selaku tergugat mengungkit mengenai pengajuan permohonan dengan iktikad tidak baik yang dilakukan PT. Ratania Khatulistiwa selaku penggugat.

\section{III.Penutup}

\section{A. Kesimpulan}

Pada bab terakhir ini, penulis membuat suatu kesimpulan yang ada, kemudian dari penguraian jawaban tersebut, penulis akan memberikan saran-saran sebagai alternatif pemecahan masalahan. Maka penulis dapat menarik kesimpulan bahwa kesimpulan dan saran sebagai berikut :

Putusan PN No. 99/PDT.SUS-MEREK/2013/PN.NAIAGA.Jkt.Pst. Jo Putusan Mahkamah Agung No. 264 K/Pst.Sus-HKI/2015 mengenai merek terkenal IKEA tidak sesuai dengan UU Merek 2001 maupun UU Merek 2016 dimana hakim dalam memutuskan putusan tersebut tidak 
sesuai dengan UU Merek dimana hakim tidak mempertimbangkan pemahaman mengenai merek terkenal. Maka dapat dikatakan hakim telah salah dalam pertimbangan dan memutus putusan tersebut, dimana Pasal 16 TRIPs yang menyatakan bahwa semua negara perserta atau anggota Konvensi Paris wajib memberikan perlindungan terhadap merek terkenal. Sehingga dalam memutuskan putusan tersebut hakim telah memberikan pemahaman yang salah terhadap merek terkenal itu sendiri.

\section{B. Saran}

Berdasarkan hasil penelitian yang telah dilakukan, penulis dapat menyampaikan beberapa saran terkait dengan permasalahan yang diangkat oleh penulis, yaitu bagi pemerintah Indonesianya sebaiknya lebih bisa menyawasi penerapan hukum atau implementasi dari peraturan yang sudah dibuat agar dapat memberikan rasa keadilan bagi para pihak yang bersengketa, sehingga tidak terulang kembali sengketa tentang peniruan merek. Diharapkan pula kepada Ditjen HKI agar secara tegas menolak pendaftaran merek baru yang memiliki persamaan pada pokoknya atau keseluruhannya dengan merek pihak lain yang telah terdaftar terlebih dahulu dan lebih mengetahui dasar diajukannya pendaftaran merek yang sama milik pihak lain agar tidak merugikan dan menimbulkan kebingungan bagi masyarakat. Bagi masyarakat Indonesia sebaiknya dapat ikut berpartisipasi dalam penegakan hukum dan perlindungan terhadap KI khususnya di bidang merek. Masyarakat Indonesia seharusnya bisa lebih menaati dan mengikuti peraturan yang telah dibuat oleh Pemerintah Indonesia. Masyarakat Indonesia juga diharapkan sadar akan sanksi terhadap peniruan merek yang sudah terdaftar khususnya merek terkenal dalam kegiatan perdagangan, sehingga dapat meminimalisir terjadinya pelanggaran merek di Indonesia.

\section{IV.Daftar Pustaka}


Astarani, Dwi Rezki Sri. 2009. Penghapusan Merek Terdaftar Berdasarkan UU No.15 Tahun 2001 Tentang Merek Dihubungkan Dengan TRIPsWTO. Bandung : PT. Alumni.

Jened. Rahmi, 2017. Hukum Merek (Trademark Law) : Dalam Era Global dan Integrasi Ekonomi. Jakarta : Kencana.

Linsey. 2013. Hak Kekayaan Intelektual : Suatu Pengantar. Bandung : PT. Alumni.

Margono, Suyud. 2011. Hak Milik Industrial : Pengaturan dan Praktik di Indonesia. Bogor: Ghalia Indonesia.

Marzuki, Peter Mahmud. 2015. Penelitian Hukum, Edisi Revisi. Jakarta : Prenadamedia Group.

Purba, Achmad Zen Umar Purba. Hak Kekayaan Intelektual Pasca TRIPs. Bandung : Alumni.

Roisah, Kholis. 2015. Konsep Hukum Hak Kekayaan Intelektual : Sejarah, Pengertian dan Filosofi Pengakuan HKI dari Masa ke Masa. Jawa Timur : Setara Press.

Saidin, OK. 2015. Aspek Hukum Hak Kekayaan Intelektual : Intellectual Property Rights. Jakarta : PT. Raja Grafindo Persada.

Sutedi, Adrian. 2013. Hak Atas Kekayaan Intelektual. Jakarta : Sinar Grafika.

Soelistyo, Henry. 2017. Bad Faith Dalam Hukum Merek. Yogyakarta : PT Maharsa Artha Mulia.

Soekanto, Soerjono. 2010. Pengantar Penelitian Hukum. Jakarta : UI Press.

Soekanto, Soerjono dan Sri Mamudji. 2004. Penulisan Hukum Normatif. Jakarta : Raja Grafindo.

Utomo, Tomi Suryo. 2010. Hak Kekayaan Intelektual (HKI) di Era Global : Sebuah Kajian Kontemporer. Yogyakarta : Graha Ilmu.

Indonesia, BBC. "MA Hapuskan Merek, Toko IKEA di Indonesia Tetap Buka”. http://www.bbc.com/indonesia/majalah/2016/02/160213_majalah_bisn is_indonesia_ikea. Diakses pada tanggal 20 Desember 2018.

Pengetahuan, Kanal. "Pengertian Hak Atas Kekayaan Intelektual (HaKI)". https://www.kanal.web.id/2016/10/hak-atas-kekayaan-intelektual.html. Diakses pada tanggal 20 Desember 2018.

Setiadharma, Prayudi. " Sedikit Kisah Mengenai Tentang Hapusnya Merek IKEA". https://www.hki.co.id/opini. Diakses pada tanggal 20 Desember 2018. 

Penerapan Merek Terdaftar Tidak Digunakan (Non-Use Marks) Analisis Kasus Antara Inter Ikea System BV dan PT. Ratania Khatulistiwa Putusan Mahkamah Agung No. 264 K/Pdt.Sus-HKI/2015 